\title{
Pulmonary impairment in workers exposed to silicon carbide
}

\author{
G Marcer, G Bernardi, G B Bartolucci, G Mastrangelo, U Belluco, A Camposampiero, B Saia
}

\begin{abstract}
Two hundred and sixty seven workers employed in the manufacture of silicon carbide (SiC) were examined to determine the effects of exposure to contaminants ( $\mathrm{SiC}$, quartz, and $\mathrm{SO}_{2}$ ) in the workplace on pulmonary function. No exposure concentrations exceeded the current permissible limits. Ten subjects $(3 \cdot 7 \%)$ showed rounded opacities (profusion $\geqslant 1 / 0$ ). Two subjects employed only in the final stages of the production process and not exposed to crystalline silica showed opacities (profusion q1/0 and q2/1) on $x$ ray film suggesting a role of $\mathrm{SiC}$ in the genesis of interstitial lung disease. Chest abnormalities on $x$ ray film were correlated with cumulative exposure to dust and pulmonary function was affected by cumulative dust exposure, profusion of opacities, and smoking. It is concluded that the current standards do not provide adequate protection against pneumoconiosis and chronic pulmonary disease in this industry.
\end{abstract}

In recent years several epidemiological and clinical investigations have suggested that workers employed in silicon carbide ( $\mathrm{SiC}$ ) manufacture may present with specific occupational lung disorders when exposed to contaminants not exceeding current standards. ${ }^{1-3}$

This study was conducted to determine the pulmonary effects of exposure to contaminants ( $\mathrm{SiC}$, quartz, $\mathrm{SO}_{2}$ ) developed during the production of $\mathrm{SiC}$ abrasive (carborundum).

\section{Material and methods}

SILICON CARBIDE PROCESS

The manufacturing process consists of running an

Institute of Occupational Medicine

G Marcer, G Bernardi, G B Bartolucci, G Mastrangelo, B Saia

Institute of Industrial Chemistry, University of Padua, Italy

U Belluco

Department of Radiology, Padua, Italy

A Camposampiero electric current through a graphite electrode that lies in a mixture of petroleum coke, high purity crystalline silica, and sawdust. The plant investigated used Acheson furnaces, which heated the mixture to $2300^{\circ} \mathrm{C}$. Silica reacts with the carbon in the coke and produces $\mathrm{SiC}$ and $\mathrm{CO}$.

The production process includes: (1) mixture of raw materials; (2) charge of furnaces; (3) firing; (4) cooling; (5) disassembling of furnaces. The lumps of $\mathrm{SiC}$ are then broken with pneumatically powered chisels. The final products are crushed, screened into several sizes, and stored before shipping out to users.

Six four-furnace batteries were in the plant: while one furnace was firing, the others within each battery were at the cooling or disassembling stage. The exposure to contaminants was variable with time; no one worked on the furnace during the heating cycle, but many worked nearby. The heating cycle was performed at night and during the weekend to reduce the power cost.

Workers employed in the manufacture of SiC may be exposed to several contaminants including silica and $\mathrm{SiC}$ dust, $\mathrm{SO}_{2}$ resulting from impurities of the coke, and $\mathrm{CO}$ which burns at the surface of the furnaces. Hydrocarbon fumes are also released during pyrolysis of the petroleum coke.

\section{EXPOSURE EVALUATION}

Exposures were measured by personal sampling and sample collections were grouped by job category. A total of 135 samples were collected, 120 to measure respirable dusts and 15 to measure exposure to $\mathrm{SO}_{2}$. Respirable particulate dust was collected on a weighed filter of porosity $0.8 \mu \mathrm{m}$ made of acetate and cellulose nitrate; the filters were conditioned, before and after sampling, at $100^{\circ} \mathrm{C}$ for two hours to eliminate absorbed humidity and weighed on a precision scale to seven decimal places. Each filter was pretreated in a Lippmann cyclone to remove nonrespirable particles. Quartz and crystobalite were measured by absorption in hydrogen peroxide and titration of the resulting sulphuric acid solution according to the method of the National Institute for Occupational Safety and Health. ${ }^{4}$ Air was drawn at $0 \cdot 8 \mathrm{l} / \mathrm{min}$ through impingers containing hydrogen peroxide.

Individual cumulative exposures to respirable 
Table 1 Concentrations $\left(\mathrm{mg} / \mathrm{m}^{3}\right)$ of respirable dusts, quartz, and crystobalite by job category

\begin{tabular}{|c|c|c|c|c|c|}
\hline \multirow[b]{2}{*}{ Job category } & \multirow[b]{2}{*}{ No of samples } & \multicolumn{2}{|l|}{ Respirable dust } & \multirow[b]{2}{*}{ Quartz (range) } & \multirow[b]{2}{*}{ Crystobalite (range) } \\
\hline & & Geometric mean & Range & & \\
\hline $\begin{array}{l}\text { Mixer } \\
\text { Furnace } \\
\text { Screen } 1 \\
\text { Crusher } \\
\text { Grinding } \\
\text { Screen } 2 \\
\text { Storage }\end{array}$ & $\begin{array}{r}12 \\
39 \\
13 \\
14 \\
7 \\
31 \\
4\end{array}$ & $\begin{array}{l}0.85 \\
0.34 \\
0.78 \\
0.30 \\
0.50 \\
1.00 \\
0.44\end{array}$ & $\begin{array}{l}0.14-2.97 \\
0.11-1.25 \\
0.16-2.95 \\
0.13-0.86 \\
0.14-1.50 \\
0.10-7.82 \\
0.30-0.63\end{array}$ & $\begin{array}{l}0-0.037 \\
0-0.003 \\
\text { absent } \\
\text { absent } \\
\text { absent } \\
\text { absent } \\
\text { absent }\end{array}$ & $\begin{array}{l}0-0.023 \\
0-0.010 \\
0-0.018 \\
0-0.012 \\
0-0.008 \\
\text { absent } \\
\text { absent }\end{array}$ \\
\hline
\end{tabular}

dusts and $\mathrm{SO}_{2}$ were calculated as suggested by Peters et $a l^{1}$; the product of the time spent in each job and its mean exposure concentration was expressed as $\mathrm{mg} /$ $\mathrm{m}^{3} \times$ years for cumulative dust and $\mathrm{ppm} \times$ years for cumulative $\mathrm{SO}_{2}$ ).

\section{SUBJECTS}

We examined 141 subjects at work in the factory during February 1988. Attempts were made to contact 164 workers employed in the past in $\mathrm{SiC}$ production for at least two years between 1983 and 1987 , to act as controls; twelve of these subjects were dead and 26 refused to participate, leaving a final control group of 126 ex-workers.

\section{HEALTH EFFECTS}

The investigation was carried out during five consecutive days in February 1988. Relevant information on health and smoking habits was obtained from the questionnaire of the European Community of Coal and Steel that deals with chronic bronchitis and emphysema. ${ }^{5}$ This was administered by three trained interviewers who also completed forms describing the subjects' past exposure in dusty industries, as well as present and past jobs in the production of $\mathrm{SiC}$.

Tests of pulmonary function were performed with a computerised spirometer in the first aid room of the factory. Forced vital capacity (FVC) and forced expiratory volume in one second $\left(\mathrm{FEV}_{1}\right)$ were measured with the subject in a seated position wearing a nose clip. The maximum value was taken from three satisfactory tracings; values were adjusted for body temperature, pressure, and saturation. The predicted values used were those quoted by the European Community of Coal and Steel. ${ }^{\circ}$

Standard posteroanterior chest radiographs were taken according to International Labour Office (ILO) standards. ${ }^{7} x$ Ray films were read by two independent physicians and classified by the ILO international classification of radiographs for pneumoconiosis ${ }^{7}$ without knowledge of age, exposure, or other information.

\section{STATISTICAL ANALYSIS}

The FVC and $\mathrm{FEV}_{1}$ were presented as a percentage of the predicted values to adjust for differences in age and height; these values were then grouped according to several variables-namely, smoking, particulate exposure, exposure to $\mathrm{SO}_{2}$, and profusion of radiographic opacities. Non-parametric one way analysis of variance (Kruskal-Wallis test ${ }^{8}$ ) was performed to assess the significance of group differences. In tables 4-8 the $p$ values generated from the Kruskal-Wallis test are reported.

A binary $(0,1)$ dependent variable was created in which 1 and 0 indicates $x$ ray film profusion categories higher or equal to $0 / 1$ and 0 respectively; a stepwise logistic regression ${ }^{8}$ was then fitted to assess the effect of the independent variables: age, smoking, years worked, particulate exposure, and exposure to $\mathrm{SO}_{2}$ on radiographic profusion. A multiple linear regression ${ }^{8}$ was used to find the best subset of predictor variables for $\mathrm{FVC}$ and $\mathrm{FEV}_{1}$ among these independent variables.

\section{Results}

EXPOSURES TO AIRBORNE DUSTS AND $\mathrm{SO}_{2}$

Table 1 shows the concentrations of respirable dusts. Average exposures were all below the existing standards for permissible exposure; in some cases high values in the screening, mixing, and selection areas were found. The concentrations of quartz and crystobalite were always low. The geometric mean concentration of $\mathrm{SO}_{2}$ was $0.05 \mathrm{ppm}$, with a maximum concentration of $0.4 \mathrm{ppm}$ in the furnace.

\section{SUBJECTS}

The final study group consisted of 267 subjects ( 141 workers and 126 ex-workers). Table 2 reports the average age, smoking habits, years worked, and

Table 2 Age, smoking and exposure data for $267 \mathrm{SiC}$ production workers

\begin{tabular}{ll}
\hline Age $(\mathrm{y})$ & $45 \cdot 9(12 \cdot 7)$ \\
Never smokers (\%) & $38 \cdot 8$ \\
Current smokers $(\%)$ & $40 \cdot 1$ \\
Ex-smokers $(\%)$ & $21 \cdot 0$ \\
Years worked & $15 \cdot 2(8 \cdot 9)$ \\
Cumulative dust exposure $\left(\mathrm{mg} / \mathrm{m}^{3} \times\right.$ years $)$ & $9 \cdot 7(12 \cdot 1)$ \\
Cumulative $\mathrm{SO}_{2}$ exposure $(\mathrm{ppm} \times$ years $)$ & $0 \cdot 6(1 \cdot 3)$ \\
\hline
\end{tabular}

Standard deviation in parentheses. 
Table 3 Frequency of radiographic abnormalities in workers $(n=141)$ and ex workers $(n=126)$

\begin{tabular}{lccc}
\hline & $\begin{array}{l}\text { Workers } \\
\text { Profusion }\end{array}$ & $\begin{array}{l}\text { Ex-workers } \\
\text { No }(\%)\end{array}$ & $\begin{array}{c}\text { Total } \\
\text { No }(\%)\end{array}$ \\
\hline None & $130(92 \cdot 2)$ & $110(87 \cdot 3)$ & $240(89 \cdot 9)$ \\
$0 / 1$ & $8(5 \cdot 7)$ & $9(7 \cdot 1)$ & $17(6 \cdot 4)$ \\
$1 / 0$ & $2(1 \cdot 4)$ & $1(0 \cdot 8)$ & $3(0 \cdot 1)$ \\
$\geqslant 1 / 1$ & $1(0 \cdot 7)$ & $6(4 \cdot 8)$ & $7(2 \cdot 6)$ \\
\hline
\end{tabular}

Table 4 Average cumulative particulate exposure $\left(\mathrm{mg} / \mathrm{m}^{3}\right.$ $\times$ years) by radiographic profusion

\begin{tabular}{ccc}
\hline Profusion & No of cases & $\begin{array}{l}\text { Particulate exposure } \\
\text { geometric mean }(S D)\end{array}$ \\
\hline None & 240 & $8 \cdot 8(11 \cdot 1)$ \\
$0 / 1$ & 17 & $13 \cdot 7(13 \cdot 9)$ \\
$1 / 0$ & 3 & $29 \cdot 8(30 \cdot 8)$ \\
$1 / 1$ & 3 & $20 \cdot 4(15 \cdot 5)$ \\
$>1 / 1$ & 4 & $25 \cdot 3(20 \cdot 1)$ \\
\hline
\end{tabular}

$\mathrm{p}<0.03$.

Table 5 Effect of smoking on pulmonary function

\begin{tabular}{llll}
\hline & $\begin{array}{l}\text { Smokers } \\
(\% \text { predicted }) \\
n=163\end{array}$ & $\begin{array}{l}\text { Never smokers } \\
(\% \text { predicted }) \\
n=104\end{array}$ & p Value \\
\hline FVC & 94.0 & $97 \cdot 1$ & $<0.08 \mathrm{NS}$ \\
FEV $_{1}$ & 96.4 & $104 \cdot 2$ & $<0.0002$ \\
\hline
\end{tabular}

cumulative exposure to dust and $\mathrm{SO}_{2}$. Most $(92 \cdot 9 \%)$ of the ex-worker group were distributed in the age classes over 50 years. Duration of exposure of more than 20 years was found in $54.0 \%$ of ex-workers and $23.4 \%$ of workers.

The percentage of smokers was similar $(41 \cdot 1 \%$ and $38.9 \%$ ) but more ex-smokers were in the ex-worker group $(25.4 \%)$ then in the worker group $(17 \cdot 1 \%)$. Smokers and ex-smokers were considered together in the analyses.

\section{RADIOGRAPHIC FINDINGS}

Table 3 reports the profusion of radiographic opacities in worker and ex-worker groups. Ten subjects (three workers and seven ex-workers) had average profusions $\geqslant 1 / 0$ and seven (one worker and six ex-workers) $\geqslant 1 / 1$. Among subjects with profusion $\geqslant 1 / 1$, three ex-workers had $1 / 1$, two $1 / 2$, and one $2 / 1$ profusion. One subject at work had a $2 / 2$ profusion. Linear opacities (profusion 1/0) were found in one case only (worker group).

The duration of exposure in workers with opacities profusion $\geqslant 1 / 1$ was 19 (SD 7.8) years (range 8-29).

The average cumulative exposure to respirable particulates increased significantly $(p<0.03)$ with profusion (table 4). No relation between years at work and cumulative exposure to $\mathrm{SO}_{2}$ was found.

Table 5 shows the effect of smoking habits on pulmonary function $\left(\mathrm{FVC}\right.$ and $\left.\mathrm{FEV}_{1}\right)$. The values are presented as a percentage of those predicted. Significant differences $(p<0.0002)$ between smokers and never smokers were found for $\mathrm{FEV}_{1}$ measures.

Tables 6 and 7 present the degrees of pulmonary function related to cumulative exposure. Cumulative exposure to respirable particulates affected FVC and $\mathrm{FEV}_{1}$ significantly but only in smokers $(\mathrm{p}<0.0015$ and $p<0.0027$ respectively). No significant effect of cumulative exposure to $\mathrm{SO}_{2}$ was shown for either smokers or never smokers. The influence of the

Table 6 Effect of cumulative particulate exposure $\left(\mathrm{mg} / \mathrm{m}^{3}\right.$ $\times$ years) on percentage predicted pulmonary function by smoking

\begin{tabular}{|c|c|c|c|c|c|c|}
\hline \multirow{2}{*}{$\begin{array}{l}\text { Particulate } \\
\text { exposure }\end{array}$} & \multicolumn{3}{|c|}{ Smokers } & \multicolumn{3}{|c|}{ Never smokers } \\
\hline & No & $F V C \%$ & $F E V, \%$ & No & $F V C \%$ & $F E V_{1}^{\circ}$ \% \\
\hline $\begin{array}{l}\leqslant 3 \cdot 6 \\
3 \cdot 7-7 \cdot 4 \\
7 \cdot 5-14 \cdot 9 \\
\geqslant 15\end{array}$ & $\begin{array}{l}75 \\
20 \\
30 \\
38\end{array}$ & $\begin{array}{l}96 \cdot 7 \\
98 \cdot 5 \\
94 \cdot 3 \\
86 \cdot 1\end{array}$ & $\begin{array}{r}98 \cdot 8 \\
102 \cdot 6 \\
98 \cdot 2 \\
86 \cdot 9\end{array}$ & $\begin{array}{l}50 \\
13 \\
22 \\
19\end{array}$ & $\begin{array}{r}97 \cdot 0 \\
103 \cdot 7 \\
97 \cdot 5 \\
92 \cdot 3\end{array}$ & $\begin{array}{r}104 \cdot 0 \\
112 \cdot 5 \\
104 \cdot 3 \\
99 \cdot 0\end{array}$ \\
\hline p Value & & $<0.0015$ & $;<0.0027$ & & NS & NS \\
\hline
\end{tabular}

Table 7 Effect of cumulative exposure to $\mathrm{SO}_{2}$ (ppm $\times$ years) on percentage predicted pulmonary function by smoking

\begin{tabular}{|c|c|c|c|c|c|c|}
\hline \multirow{2}{*}{$\begin{array}{l}\mathrm{SO}_{2} \\
\text { exposure }\end{array}$} & \multicolumn{3}{|c|}{ Smokers } & \multicolumn{3}{|c|}{ Never-smokers } \\
\hline & No & $F V C \%$ & $F E V, \%$ & No & $F V C$ & $F E V_{1} \%$ \\
\hline $\begin{array}{l}\leqslant 0.37 \\
0.38-0.74 \\
0.75-2 \cdot 2 \\
>2.2\end{array}$ & $\begin{array}{r}8 \\
7 \\
34 \\
114\end{array}$ & $\begin{array}{l}93 \cdot 6 \\
90 \cdot 5 \\
98 \cdot 1 \\
93 \cdot 0\end{array}$ & $\begin{array}{l}97 \cdot 5 \\
92 \cdot 4 \\
98 \cdot 9 \\
95 \cdot 8\end{array}$ & $\begin{array}{r}7 \\
6 \\
21 \\
70\end{array}$ & $\begin{array}{l}98 \cdot 1 \\
99 \cdot 9 \\
96 \cdot 9 \\
96 \cdot 8\end{array}$ & $\begin{array}{l}102 \cdot 5 \\
105 \cdot 4 \\
104 \cdot 0 \\
104 \cdot 3\end{array}$ \\
\hline p Value & & NS & NS & & NS & NS \\
\hline
\end{tabular}

Table 8 Percentage predicted pulmonary function by profusion of radiographic opacities and smoking

\begin{tabular}{|c|c|c|c|c|c|c|c|c|c|}
\hline \multirow[b]{2}{*}{ Profusion } & \multicolumn{3}{|c|}{ Smokers } & \multicolumn{3}{|c|}{ Never smokers } & \multicolumn{3}{|c|}{ Total } \\
\hline & No & $F V C \%$ & $F E V, \%$ & No & $F V C \%$ & $F E V, \%$ & No & $F V C \%$ & $F E V, \%$ \\
\hline p Value & & $<0.0029$ & $<0.0017$ & & NS & NS & & $<0.001$ & $<0.001$ \\
\hline
\end{tabular}


Table 9 Significant independent variables identified by logistic regression and multiple linear regression

\begin{tabular}{|c|c|c|c|c|}
\hline Dependent variable & Independent variable & Improvement $\chi^{2}$ & $T$-stat & p Value \\
\hline \multicolumn{5}{|c|}{ Logistic regression } \\
\hline Profusion & Particulate exposure & $6 \cdot 232$ & - & $<0.013$ \\
\hline \multicolumn{5}{|c|}{ Multiple linear regression } \\
\hline$\%$ Predicted FVC & $\begin{array}{l}\text { Particulate exposure } \\
\text { Profusion }\end{array}$ & - & $\begin{array}{l}-3.03 \\
-3.04\end{array}$ & $\begin{array}{l}<0.003 \\
<0.003\end{array}$ \\
\hline$\%$ Predicted FEV, & $\begin{array}{l}\text { Particulate exposure } \\
\text { Profusion } \\
\text { Smoking }\end{array}$ & $\frac{-}{-}$ & $\begin{array}{l}-3.56 \\
-2.90 \\
-2 \cdot 22\end{array}$ & $\begin{array}{l}<0.0001 \\
<0.004 \\
<0.027\end{array}$ \\
\hline
\end{tabular}

duration of exposure on pulmonary function was not significant.

Table 8 shows parameters of pulmonary function broken down by radiographic profusion in smokers and never smokers. A significant negative trend between both FVC and $\mathrm{FEV}_{1}$ and profusion of opacities was found in the total population $(\mathrm{p}<0.001$ in both cases) and in the smokers ( $\mathrm{p}<0.0029$ and $\mathrm{p}<0.0017$ respectively) but not in never smokers alone.

Table 9 summarises the results of multiple regression to determine the major effects of independent variables on pulmonary function and profusion of opacities. The profusion of opacities related significantly to cumulative exposure to dust. Both FVC and $F E V_{1}$ had a significantly negative relation with cumulative exposure to dust and profusion of opacities; $\mathrm{FEV}_{1}$ was also associated with smoking habit.

\section{Discussion}

Silicon carbide is generally considered inert in human lungs. ${ }^{9}$ Research conducted with laboratory animals supports this view; when exposed to a high concentration of $\mathrm{SiC}$ dust they failed to develop fibrosis. ${ }^{10}$ Nevertheless, abnormal chest radiographs among the workers exposed to $\mathrm{SiC}$ have been described. ${ }^{11-13}$ In more recent years investigations in the carborundum industry have documented an excess of radiographic abnormalities (compatible with pneumoconiosis) and a significant reduction of pulmonary functions. These were related either to cumulative exposure to dust and $\mathrm{SO}_{2}$ or to smoking habits ${ }^{1}$ in conditions in which the exposure concentrations were substantially below the threshold limit value. ${ }^{14}$ Finally, Osterman et al found a statistically significant loss of pulmonary function related to duration at work in production of $\mathrm{SiC}$, which was independent of smoking habits. ${ }^{3}$

The pneumoconiosis in workers involved with $\mathrm{SiC}$ production has generally been attributed to crystalline silica used in the process. Yet Funahashi $e t a l^{2}$ conducted a study using $x$ ray diffraction analysis of open lung biopsies on two $\mathrm{SiC}$ production workers with diffuse reticulonodular densities on radiographs. The authors identified six different silicon carbides but not significant amounts of quartz. They interpreted these findings as suggesting that some silicon carbides are more fibrogenic than others. Recent findings, however, raised the possibility that mineral dusts that are inert when in a particulate form, may have biological activity when they occur in a fibrous form. ${ }^{1516}$ Masse $e t a l^{17}$ and Durand et $a l{ }^{18}$ have documented lung lesions sufficiently distinct from those of silicosis and asbestosis to allow recognition as a separate entity.

In the present study, conducted on a population with a mean duration of exposure of 19.0 (SD 7.8) years (range 8-29), we have been able to show a lower prevalence $(2.6 \%)$ of pneumoconiosis (profusion $\geqslant 1 / 1)$ than that $(14 \%)$ reported by Peters et al ${ }^{1}$ The profusion of opacities was related to cumulative exposure to dust. Two subjects (profusion $\mathrm{q} 1 / 0$ and q 2/1) were employed only in the final stages (screening and storage) of the production process and therefore they were not exposed to crystalline silica. The cumulative exposure to dust also determined impairments of pulmonary function, particularly in smokers. No effect of cumulative exposure to $\mathrm{SO}_{2}$ was shown. A significant negative trend between both FVC and $F E V_{1}$ and profusion of opacities was found only in smokers.

These results confirm the findings from other epidemiological studies. ${ }^{1}$ It can therefore be suggested that the differences in prevalence of pneumoconiosis is probably related to lower concentrations of total and respirable dust and crystalline silica measured in the $\mathrm{SiC}$ factory. ${ }^{14}$

In conclusion, our data show the presence of a respiratory risk in the manufacture of $\mathrm{SiC}$ at exposures below current permissible limits. The finding of two cases of pneumoconiosis in workers not exposed to silica strongly suggests a possible role for $\mathrm{SiC}$ in the genesis of interstitial lung disease.

This leads us to consider, in agreement with others, ${ }^{15}$ that the current permissible limits for exposure to the mixture of contaminants in SiC production are too high to protect the health of exposed workers. 
Requests for reprints to: Dr Guido Marcer, Istituto di Medicina del Lavoro, Via Facciolati, 71-35127 Padova, Italy.

1 Peters JM, Smith TJ, Bertstein L, et al. Pulmonary effects of exposure in silicon carbide manufacturing. $\mathrm{Br} J$ Ind Med 1984;41:109-15.

2 Funahashi A, Schueter D, Pintar KA, et al. Pneumoconiosis in workers exposed to silicon carbide. Am Rev Respir Dis 1984;129:635-40.

3 Osterman JW, Greaves JA, Smith TJ, et al. Work related decrement in pulmonary function in silicon carbide production workers. Br J Ind Med 1989;46:708-16.

4 Taylor DG. NIOSH manual of analytical methods. Vol I. Washington DC: US Government Printing Office, 1977:146-1 to 146-7. (DHEW (NIOSH) publ No 77-157A.)

5 Sartorelli E, Scotti P. Questionario per lo studio della bronchite cronica e dell'enfisema polmonare. Med Lav 1965;56:39.

6 Quanjer PH. Standardized lung function testing. Report of working party on standardization of lung function tests. Bull Eur Physiopathol Respir 1983;19(suppl 5):1-95.

7 International Labour Office. Guidelines for the use of ILO international classification of radiographs of pneumoconioses. Geneva: ILO, 1980 (Occupational safety and health series No 22.)

8 Dixon WJ, Brown MB, Engelman L, Hill MA, Jenrich RI.
BMPD Statistical Software Manual. Berkely CA: University of California. Press, 1988.

9 Parkes WR. Occupational lung disorders. 2nd edition. London: Butterworths, 1982:130-31.

10 Gardner LU. Experimental production of silicosis. United States Public Health Report 1985;50:695-702.

11 Clark WI. The dust hazard in the abrasive industry. Second study. Journal of Industrial Hygiene 1929;11:92-6.

12 Smith AR, Perina AE. Pneumoconiosis from synthetic abrasive material. Occup Med 1948;5:396-402.

13 Brusgaard A. Pneumoconiosis in silicon carbide workers. In "Proceedings of the Ninth Int Congr Ind Med". London, 1948:13-7.

14 Smith TJ, Hammond SK, Laidlaw F, Fine S. Respiratory exposures associated with silicon carbide production: estimation of cumulative exposures for an epidemiological study. Br J Ind Med 1984;41:100-8.

15 Bye E, Wijnand E, Gionnes J, Sorbroden E. Occurrences of airborne silicon carbide fibers during industrial production of silicon carbide. Scand J Environ Health 1985;11:111-15.

16 Begin R, Dufresne A, Cantin A, et al. Carborundum pneumoconiosis. Chest 1989;95:842-9.

17 Massé S, Begin R, Cantin A. Pathology of silicon carbide pneumoconiosis. Modern Pathology 1988;1:104-8.

18 Durand $\mathrm{P}$, Bégin $\mathrm{R}$, Samson $\mathrm{L}$, et al. Silicon carbide pneumoconiosis: a radiographic assessment. Am J Ind Med 1991;20:37-47.

Accepted 4 November 1991 